\author{
(c) $(7)$ \\ Jurnal Terapan Manajemen dan Bisnis is licensed under \\ A Creative Commons Attribution-Non_Commercial 4.0 International License.
}

\title{
STOCK RETURN IN INDONESIA BANKING COMPANIES: INVESTMENT DECISIONS, DIVIDEND POLICY, INSTITUTIONAL OWNERSHIP, INTEREST RATE
}

\author{
Enggar Bayu Kusumaningrum ${ }^{1)}$, Hasna Noor Alifa ${ }^{2)}$, Amrie Firmansyah ${ }^{3)}$ \\ 1) STAN Polytechnic of State Finance, Tangerang, Indonesia \\ E-mail: enggarebk@yahoo.co.id \\ 2) STAN Polytechnic of State Finance, Tangerang, Indonesia \\ E-mail: nooralifahasna@gmail.com \\ 3) STAN Polytechnic of State Finance, Tangerang, Indonesia \\ E-mail: Amrie.firmansyah@gmail.com
}

\begin{abstract}
This study aims to determine the effect of investment decisions, dividend policy, institutional ownership, and interest rates on stock returns. This research is a quantitative study using secondary data and multiple regression analysis methods. Data was sourced from www.idx.com and finance.yahoo.com consist of data and information from company financial statements and stock prices. Purposive sampling was chosen as the sampling method and obtained 35 banking companies for three years, so the total sample is 105 firmyear. The results suggest that investment decisions, dividend policy, and institutional ownership are not associated with stock returns, while interest rates negatively affected stock returns. This study indicates that banking companies make significant innovations in their products so that the investment objective is to support the company's operational activities and increase company value from investors' perspective. High deposit interest rates provide investors information that investors will benefit more if they invest their funds in the bank rather than investing it in the banking sector, which is likely to have a greater risk than investing in banks, especially in the form of deposits.
\end{abstract}

Keywords: Dividend Policy; Institutional Ownership; Investment Decision; Stock Return; Interest Rate.

\section{Introduction}

Since the first COVID-19 sufferers were found in Indonesia, the Indonesian capital market has been in chaos. Regulators had strived for policies, but they were still unable to withstand the Jakarta Composite Index (IHSG). The first case of COVID-19 that appeared for the first time in Indonesia resulted in the Indonesian Stock Exchange's Jakarta Composite Index (IHSG) reacting (finance.detik.com), IHSG closed down 91.46 points (1.68\%) to the position of 5,361.25. For example, in trading on March 9, 2020, IHSG closed down by $6.5 \%$ to 5,136 levels. Such a profound fall in the IHSG is an infrequent event unless it is in severe circumstances such as the economic crisis. The regulators have also tried hard by issuing various policies to contain the IHSG collapse. Fund managers are not always accurate in predicting market direction because many factors determine stock prices. If investors can 
always predict the market's direction correctly and have the guts to transact, undoubtedly, an investor will always win the game in the market and always get capital gains (Andansari et al., 2016). There are no investors or fund managers who have such abilities because it is complicated to predict stock prices. The capital market is also known for its high risk-high return characteristics, meaning that investment in capital market shares provides high returns and has high-risk potential. Before deciding to invest their funds in the company, shareholders need to assess the company's prospects. From an investor's point of view, one of the essential indicators for assessing a company's prospects in the future is assessing the financial performance and returns obtained by shareholders (Astarina et al., 2019). The factors that influence stock returns are microeconomic factors and macroeconomic factors. Microeconomic factors are factors within the company, while macroeconomic factors are factors outside the company. Astuti et al. (2016) stated that stock prices would be immediately affected by changes in macroeconomic factors because investors react more quickly. With the influence of macroeconomic factors that are difficult to predict and anticipate, investors can anticipate and estimate the return obtained by looking at its financial performance. Management will provide bad news and good news signals reflected in the company's financial statements so that investors can capture and analyze the signals given by management to calculate the returns that will be obtained. Several factors that test stock returns have been carried out in previous research, such as investment decisions (Kusumawati, 2016; Akbar \& Herianingrum, 2015; Andansari et al., 2016; Piristina \& Khairunnisa, 2019), funding decisions (Kusumawati, 2016), dividend policy (Pratiwi, 2015; Astarina et al., 2019; Kusumawati, 2016; Fitri, 2017), institutional ownership (Murwaningsari, 2012; Nuraeni, 2012), interest rates (Mahilo \& Parengkuan, 2015; Suriyani \& Sudiartha, 2018; Setyaningrum \& Muljono, 2016; Nasir and Mirza, 2011), profitability (Mondayri et al., 2020; Andansari et al., 2016; Nuraeni, 2012), leverage (Mondayri et al., 2020, Putra dan Dana, 2016), Liquidity ( Geno et al., 2020; Putra \& Dana, 2016).

Research on the relationship between the effect of investment decisions on stock returns is vital to be appointed. First, investment decisions are essential for the company's survival because they involve funds allocated to particular investments to generate future profits. Second, several tests on the effect of investment decisions on stock returns show different results. Kusumawati (2016) and Piristina and Khairunnisa (2019) have researched investment decisions on stock returns who found that investment decisions do not affect stock returns. However, the results obtained are different from the results conducted by Akbar and Herianingrum (2015) and Andansari (2016), who found that investment decisions have a negative effect on stock returns.

Apart from investing, investors also look at the company's dividend policy to predict their investment's future value. Research on dividend policy is necessary to raise because dividend policy is related to the decision of the directors in terms of whether the profit generated by the company at the end of the period will be distributed to shareholders (dividends) or the profit will be retained as an increase in the company's capital to be used in activities or investments future development of the company. Research on dividend policy on stock returns was conducted by Pratiwi (2015), Fitri (2017), Astarina et al. (2019), and Kusumawati (2016). Pratiwi (2015) concluded that dividend policy has a significant negative effect on stock returns. This result is different from Fitri (2017), who found that dividend policy has no significant effect on stock returns. The results obtained by Fitri (2017) are in line with the results obtained by Kusumawati (2016), who also found that dividend policy has no significant effect on stock returns. Meanwhile, Astarina et al. (2019) found conflicting results: dividend policy positively affects stock returns. 
Furthermore, research on the relationship between institutional ownership on stock returns is essential to review. Institutional ownership influences stock price movements because in maximizing the value of the company's shares, conflicts of interest often arise. Research on institutional ownership on stock returns conducted by Nuraeni (2012) concluded that institutional ownership does not affect stock returns. This result is not in line with Murwaningsari (2012), which found that institutional ownership positively affects stock returns.

Interest rates are an essential thing in banking companies because, on average, investors always expect greater investment returns. Interest rates affect production costs and the company's products' price to affect company profits and stock returns. Research on interest rates on stock returns has been conducted by Tumonggor et al. (2017) found that the interest rate does not significantly affect stock returns. It contradicts Suriyani and Sudiartha (2018), who found that interest rate positively affects stock returns. Setyaningrum and Muljono (2016) concluded that the interest rate does not significantly affect stock returns. Meanwhile, Nasir and Mirza (2011) found that deposit rates have a significant negative effect on stock returns.

The existence of testing inconsistencies in previous studies, then testing investment decisions, dividend policy, institutional ownership, and interest rates on stock returns, especially for Indonesia's banking companies. This research is expected to provide guidelines for companies to produce quality financial reports and provide bad news and good news signals to investors. This research is expected to contribute to the company's management in making investment decisions, dividend policy, institutional ownership, and interest rates to provide stock returns. This research can also be used as input for the Financial Services Authority in evaluating market risk management policies due to the macroeconomic phenomenon that occurs, namely COVID-19. Meanwhile, for investors, this research can be used as an indicator in assessing a company for making investment decisions by looking at the informativeness of financial reports as a good signal or a bad signal. Furthermore, this research can be used to reference the development of capital market-based accounting research issues, mainly information in financial reports related to stock market conditions.

\section{Literature Review and Hypothesis Development Signaling Theory}

Signaling theory is concerned with understanding how a signal is valuable or useful while other signals are useless (Gumanti, 2009). this theory examines how the signal is related to the quality reflected in it and what elements of the signal or the surrounding community keep the signal convincing and attractive. There is an impact that occurs when the signal hinted at is not very convincing or uncertain. According to Connelly et al. (2011), the signal theory is useful for describing the behavior of two parties who have different access to information. This theory reveals evidence that there is an inequality of information between the company's internal and external parties. Internal parties such as officers and directors generally have a better knowledge of the company's current condition and its prospects. It is not owned by external parties such as investors, creditors, government, and even shareholders.

The relationship between signal theory and company returns can be explained by information asymmetry between company management and investors. Macroeconomic phenomena such as the COVID-19 pandemic, which has dramatically influenced the stock price index's movement, is proof that stock returns are complicated for investors to predict. Meanwhile, company managers certainly know more about the conditions and prospects of 
their company. Companies need to disclose financial and annual reports in a transparent and accountable manner to be interested in buying shares. Information in the form of a report that is considered a good signal for investors will affect the share price, reflecting the company's wealth that issued the shares. Thus, good signals and bad signals affect the rate of return on shares of the company.

\section{Hypothesis Development}

Based on the signal theory, to reduce the asymmetry of intermediate information management and investors, management will provide whatever investments the company makes to determine its assessment using the information signals generated. One of the company's investment decisions is to increase its assets so that the company's total asset growth can show it. Investment decisions made by adding to the company's assets indicate that its value is increasing, which is reflected in its stock price, so that investment decisions have more influence on the increase in firm value, not the company's profit. It is in line with Kusumawati (2016), who proved that investment decisions have a negative effect on stock returns. Investment decisions can also be measured using the price earning ratio (PER) as used in research by Akbar and Herianingrum (2015) and Andansari et al. (2016), who found that investment decisions have a negative effect on stock returns. A low PER indicates that the company's profit is higher than the stock price, meaning that the company has high profitability and is considered to have good performance to generate high returns for investors (Andansari et al., 2016). This difference in viewpoint leads to different results. However, based on signal theory, investors respond more positively to company earnings to provide confidence regarding the return obtained than the company's stock price. Thus, the first hypothesis in this study is:

$\mathrm{H}_{1}$ : Investment decisions are negatively associated with stock returns.

Dividend policy can be received as a positive signal for stock returns that investors will receive. Dividend distribution to investors will give a positive view of the company on the stock market so that the demand for company shares increases and causes an increase in stock prices which also affects the increase in the company's stock return. This statement is in line with Astarina et al. (2019), who found that dividend policy positively affects stock returns. The results of this study are not in line with research conducted by Fitri (2017) and Kusumawati (2016), who found that dividend policy has no effect on stock returns and is not in line with Pratiwi (2015), who concluded that dividend policy has a negative effect on stock returns. Dividend policy does not affect shareholder wealth as reflected by stock returns because it is only a small part of its financial decisions. Thus, the second hypothesis in this study is:

$\mathrm{H}_{2}$ : Dividend policy is positively associated with stock returns.

Institutional ownership is the ownership of shares of a company by institutions such as insurance companies, banks, investment companies, and other institutions. Based on the signal theory, companies need to disclose the percentage of institutional ownership in financial statements to reduce information asymmetry between management and investors. The high percentage of institutional ownership in a company can indicate the functioning's functioning so that management and corporate governance systems are expected to be better. It can affect the increase in the return rate of shares produced because the monitoring function hinders opportunistic actions that managers by institutional ownership may carry out. Murwaningsari (2012) found that institutional ownership has a positive effect on stock returns. This condition is due to increased institutional ownership leading to better supervision to protect the majority and minority shareholders' interests. Shareholders get the same economic incentive in the form of abnormal returns on shares. This action impacts 
increasing its value, as indicated by the increase in stock prices and increasing stock returns. This result is not in line with Nuraeni (2012), who found that institutional ownership does not affect stock returns. Thus, the third hypothesis in this study is:

$\mathrm{H}_{3}$ : Institutional ownership is positively associated with stock returns.

High deposit interest rates will encourage people to invest their funds in banks rather than investing in the production or industrial sectors, where the risk is much greater than investing money in banks, especially in the form of deposits. Research by Nasir and Mirza (2011) found that deposit rates have an inverse relationship with stock returns. Nasir and Mirza (2011) further explain that the continuous increase in deposit rates has led to capital owners' tendency to shift their capital to time deposits. Of course, this has a negative impact on the company's share price in the capital market. Investors are less interested in investing because the return on shares to be received is smaller than the return on deposit interest. These results are in line with research conducted by Setyaningrum and Muljono (2016). Cahyono (2000) reveals two explanations for why interest rates have a negative effect on stock returns. First, an increase in interest rates changes the map of investment returns. Second, an increase in interest rates will cut corporate profits. An increase in interest rates will increase the company's interest expense to cut the company's profits. Besides, when interest rates are high, production costs will increase, and product prices will be more expensive, so that consumers may delay their purchases and choose to save their funds in the bank. It causes the company's sales to decrease so that the stock return will decrease. Meanwhile, different results are shown by Mahilo and Parengkuan (2015) and Suriyani and Sudiartha (2018), who found that interest rates do not have a significant effect on stock returns. Based on this description, the fourth hypothesis in this study is:

$\mathrm{H}_{4}$ : Interest rates are negatively associated with stock returns.

\section{Methods}

This research is a quantitative method with panel data. This study employs secondary data sourced from the financial statements of banking subsector companies listed on the Indonesia Stock Exchange from 2017 to 2019. Data was sourced from www.idx.co.id and finance.yahoo.com consist of data and information from company financial statements and stock prices. Banking sub-sector companies were selected as the population because this sub-sector has the largest number of listed companies and has a strong influence on the financial sector so that investors are expected to obtain an overview of the financial performance of the financial sector as a whole by analyzing financial performance and stock returns of the banking subsector. Then, banking is one of the sub-sectors that are prone to be affected by the crisis. The sample selection was carried out by purposive sampling as follows.

\section{Table 1 Research Sample}

\begin{tabular}{llll} 
No & Criteria & Total & Size \\
1 & Companies in the banking sub-sector per May 2020 & 44 & Companies \\
2 & $\begin{array}{l}\text { Banking subsector companies listed on the IDX after January } 1, \\
\text { Companies }\end{array}$ \\
3 & $\begin{array}{l}2017 \\
\text { Companies with incomplete financial statement data }\end{array}$ & -5 & Companies \\
4 & Companies do not have complete data & -3 & Companies \\
& $\begin{array}{l}\text { The number of companies for the sample } \\
\text { Year }\end{array}$ & 35 & Companies \\
Final sample & 3 & Year \\
\hline
\end{tabular}

Source: processed 
The dependent variable used in this study is stock returns. Stock returns in the year concerned in this study are sought by calculating capital gains or similar to the proxy used by Kusumawati (2016). However, the proxies used in this study use proxies that take into account monthly stock price movements, so the stock return is calculated as follows:

$$
\begin{aligned}
& \text { R month } \mathrm{n}=\frac{\mathrm{P} \text { end month } \mathrm{n}-\mathrm{P} \text { beginning month } \mathrm{n}}{\mathrm{P} \text { beginning month } \mathrm{n}} \\
& \text { Stock Return } \left.=((1+\text { the average R month } 1 \text { up to } 12))^{\wedge} 12\right)-1
\end{aligned}
$$

Where:

$\mathrm{R}$ month n: Stock return in month $\mathrm{n}$

$P$ beginning month $n$ : Stock price at the beginning of month $n$

$P$ end month n: Stock price at the end of month $n$

This study's independent variables consist of investment decisions, dividend policy, institutional ownership, and interest rates. An investment decision is a form of capital allocation whose realization is expected to generate benefits or gains in the future. This study uses an Earning Price Ratio (PER) for investment decision proxy, as used in Ayem and Nugroho (2016).

$$
\text { PER }=\frac{\text { Market Value of Per Share }}{\text { Earnings Per Share }}
$$

A dividend policy is a decision regarding whether the profits earned by the company will be distributed to shareholders as dividends or will be retained in the form of retained earnings to finance future investments. This study's dividend policy uses dummy variables, in line with the proxies for dividend policy in Mladenoska (2016) and Atmaja's (2009) research. When a company distributes dividends in a particular year, it will be given a value of one (1); conversely, when the company does not distribute dividends in a particular year, it will be given zero value (0).

Institutional ownership is calculated by finding the percentage of shares owned by the institution by dividing the number of shares owned by the institution by the number of shares outstanding. The proxy for institutional ownership in this study is in line with Nuraeni (2012) and Murwaningsari (2012).

$$
\text { Institutional Ownership }=\frac{\text { the number of shares owned by the institution }}{\text { the number of shares outstanding }}
$$

This study's interest rate is the time deposit interest rate or deposit interest rate because it is considered to illustrate investors' willingness to transfer their money to be saved in the form of deposits. The use of the three-month time deposit interest rate is similar to the proxies used by Firmansyah et al. (2020) and Nasir and Mirza (2011), which are calculated as follows.

$$
\text { Interest rate }=\frac{\text { the total interest rate for three }- \text { month time deposits for one year }}{4}
$$

This study also uses control variables, namely company size, and profitability. Company size reflects its size, as considered from its total assets (Han \& Lesmond, 2009) in Raningsih and Putra (2015). Company size is proxied using its total assets' logarithm, similar to the proxy used in Raningsih and Putra and Dana's research (2016).

$$
\text { Size }=\text { logarithm total assets }
$$

Profitability is a measurement of the company's overall ability to generate profits with the total assets available in the company (Purnamasari, 2017). Profitability is calculated 
by the return on assets that is the percentage of net income divided by total assets, similar to the proxy used by Purnamasari (2017).

$$
R O A=\frac{\text { net income }}{\text { total assets }}
$$

Hypothesis testing in this study uses panel data regression analysis. The research model is as follows:

SRit $=\beta 0+\beta 1 P E$ Rit $+\beta 2$ DIVit $+\beta 3$ INSOWNit $+\beta 4$ INTit $+\beta 5$ SIZEit $+\beta 6$ ROAit $+\varepsilon i t$

Where:

SRit: Return of shares of banking company $i$ in year $t$

PERit: investment decision banking company $i$ in year $t$

DIV $V_{\text {it: }}$ dividend policy banking company $\mathrm{i}$ in year $\mathrm{t}$

INSOWNit : institutional ownership banking company $\mathrm{i}$ in year $\mathrm{t}$

$\mathrm{INT}_{i t}$ : Interest rate banking company $\mathrm{i}$ in year $\mathrm{t}$

SIZE it : Size of banking company $i$ in year $t$

ROA it: Profitability banking company $i$ in year $t$

\section{Results and Discussion}

Descriptive statistics that describe the variables used in this study are listed in Table 2, as follows:

Table 2 Descriptive Statistics

\begin{tabular}{cccccc}
\hline Var. & Mean & Median & Max. & Min. & Std. Dev \\
\hline SR & 0,3841 & 0,0320 & 17,978 & $-0,4970$ & 1,8681 \\
PER & 54,761 & 18,090 & 1360,470 & $-145,57$ & 163,46 \\
DIV & 0,4190 & 0,0000 & 1,0000 & 0,0000 & 0,4957 \\
INSOWN & 0,6111 & 0,6000 & 0,9730 & 0,0600 & 0,2571 \\
INT & 0,0666 & 0,0680 & 0,0760 & 0,0590 & 0,0043 \\
SIZE & 31,403 & 31,057 & 34,887 & 28,448 & 1,9165 \\
ROA & 0,0060 & 0,0090 & 0,0313 & $-0,1123$ & 0,0191 \\
\hline
\end{tabular}

Sourced: Processed

Furthermore, the regression test using the common effect method shows the following results:

Tabel 3 The Summary of Regression Test

\begin{tabular}{ccccc}
\hline Var. & Coefficient & t-Stat & Prob. & \\
\hline C & 9,1108 & 6,7823 & 0,0000 & $* * *$ \\
PER & 0,0002 & $-0,5144$ & 0,3037 & \\
DIV & 0,1672 & $-1,6515$ & 0,0509 & $*$ \\
INSOWN & 0,0255 & $-0,1641$ & 0,4349 & \\
INT & 70,985 & $-7,6720$ & 0,0000 & $* * *$ \\
SIZE & 0,1321 & $-4,4331$ & 0,0000 & $* * *$ \\
ROA & 12,067 & 3,9719 & 0,0000 & $* * *$ \\
R $^{2}$ & & 0,3948 & & \\
Adj. R $^{2}$ & & 0,3577 & & \\
F-stat. & & 10,655 & & \\
Prob (F-stat.) & & 0,0000 & &
\end{tabular}

Source: Processed 


\section{The Association Between Investment Decisions and Stock Returns}

The hypothesis testing suggests that investment decisions are not associated with stock returns. This result is in line with Piristina and Khairunnisa (2019) and Kusumawati (2016). In investing, companies need a large capital, but investment has less influence on investors even though investment decisions can improve and develop the company. Most of the banks' investments are capital goods investments, namely buying several fixed assets or adding value to fixed assets expected to provide future benefits. However, banks' objective of investing in capital goods is to support and support their overall operational activities. Besides, banking investment needs are carried out solely to support strategic banking policies and increase banking digitization capabilities to develop business operations and services. Banks usually also invest in improving transaction services and lending and supporting their own subsidiaries' development. Banks' investments are not attractive to investors because banks do not make significant changes in their business processes, unlike technology-based companies that are required to continue to innovate, so that banking investment decisions do not increase the value of banking companies. It also indicates that banking investment decisions are made to provide customers services and are not related to investors' returns.

\section{The Association Between Dividend Policy and Stock Returns}

The hypothesis testing suggests that dividend policy is negatively associated with stock returns. The result contrasts with the hypothesis so that this result is considered that dividend policy is not associated with stock returns. It is in line with Fitri (2017) and Kusumawati (2016). Dividend distribution by banking companies is not a measure for investors in assessing the informativeness of current returns. Nowadays, banks prefer to hold profits as retained earnings to strengthen the capital of banking companies. Based on these characteristics, it can be concluded that banking investors expect profits from rising stock prices, not from dividend distribution so that investors do not consider dividends as a signal in making investment decisions. Investors do not respond that the distribution of dividends is an indication that the company will provide high returns, so the dividend policy is not following the signal theory, which is the theoretical basis of this study. Investors respond more to information other than dividends presented in the financial statements. Many factors affect dividend policy in a company and changes in share prices, and these factors interact (interdependence) and between one type of company and another company. There are also differences in policy considerations in the dividend distribution.

\section{The Association Between Institutional Ownership and Stock Returns}

The hypothesis testing suggests that institutional ownership is not associated with stock returns. In line with Nuraeni (2012), institutional ownership in companies, either in a low or high percentage, is related to banking management supervision, while return, which is reflected by stock prices, is related to investors' reactions to market conditions. If it is related to signal theory, institutional ownership is not a good signal for investors regarding the return information. Ownership of shares of other financial institutions in the banking sector is a common thing. Other financial institutions that have share ownership in a bank are not a consideration for investors in investing their capital because this only illustrates running the company's monitoring function. The monitoring function in a company is carried out to ensure that the activities that occur follow agreed procedures and plans. Monitoring also aims to prevent moral hazards. However, the role of institutional ownership as a form of monitoring does not influence in realizing good banking governance because the role of monitoring has been carried out by the Indonesia Financial Services Authority and the 
Indonesia Deposit Insurance Corporation so that investors no longer consider institutional ownership as the party with tight monitoring for banking companies

\section{Association Between Interest Rates and Stock Returns}

The hypothesis testing suggests that interest rates are negatively associated with stock returns. High deposit interest rates, following signaling theory, provide information to investors that investors will benefit more if they invest their funds in the bank rather than investing in the banking sector, which is likely to have a greater risk when compared to investing in banks, especially in the form of deposits. By placing their funds in the form of deposits, investors do not need to worry because this investment is not affected by market movements, and a deposit management system has been established, so it does not change at any time. As can be seen from the descriptive statistical analysis results, although the average deposit interest rate is lower than the average stock return, the difference between the maximum and minimum value of stock returns is extreme. On the other hand, the maximum and minimum deposit interest rates do not show extreme differences, so it can be seen that the average banking company provides consistent returns on deposits throughout the year. It is an essential consideration for investors in channeling their funds to avoid unanticipated investment risks.

In line with Nasir and Mirza (2011), high-interest rates will encourage people to invest their funds in banks rather than investing in the production sector or industrial sector where the risk is much more significant when compared to investing in banks, especially in the form of deposits, so that returns obtained will be low if the benefits obtained as a result of savings in the form of deposits are higher. Stock returns are sensitive to interest rates negatively, which indicates that stock returns will increase if the deposit rate is low, which will cause the return to be received on deposits is low. Low-interest rates will stimulate investment and economic activity, which will cause stock prices to increase. The continuous increase in deposit rates has resulted in a tendency for capital owners to shift their capital into deposits. It can have a negative impact on the company's stock returns in the capital market. Investors are less interested in investing their capital because their earnings are smaller than those obtained from deposit interest.

\section{Conclusion, Limitations, Implications}

Investments made by banks are presumably not attractive to investors because banks have not made significant changes in their business processes. The distribution of dividends by banking companies is not a measure for investors assessing current returns' informativeness. Other financial institutions that have share ownership in a bank are not a consideration for investors in investing their capital because this only illustrates running the company's monitoring function. High deposit interest rates provide investors information that investors will benefit more if they invest their funds in the bank rather than investing it in the banking sector, which is likely to have a greater risk than investing in banks, especially in the form of deposits.

This study only uses a research sample of the banking subsector for a limited period, namely for three years (2017 to 2019). Besides, this study has limitations in calculating institutional ownership. Information on institutional ownership is not clearly described in several banking companies, so it is necessary to further investigate through annual reports, which are not entirely obtained. Banks included in the category of regional banks do not explicitly explain the components of share capital based on their ownership but only explain the type of shares, namely series A and B shares. Future research can use companies other than banking to explain the nature of research variables in other industries. Future research 
can also use a sample of all company sectors on the IDX to determine the effect of all companies' variables in general.

Future research is possible to extend the study time interval from before 2017 to 2020 . Further research can use other proxies that are still not used in this study. The results indicate that banking companies make significant innovations in their products so that the investment objective is to support the company's operational activities and increase company value from investors' perspective. Furthermore, concerning institutional ownership, companies are advised to maximize the monitoring function employing share ownership by institutions so that the monitoring function is not only carried out by the Indonesian Financial Services Authority and the Indonesian Deposit Insurance Corporation. This study's results can also help current and potential investors make investment decisions, especially in the Indonesian capital market. Furthermore, the Indonesian Financial Services Authority is expected to carry out more intensive supervision of banks so that the banking sector implements credit restructuring to achieve the target number of debtors using this facility

\section{References}

Akbar, R., \& Herianingrum, S. (2015). Pengaruh price earning ratio (per), price book value (pbv) dan debt to equity ratio (DER) terhadap return saham. Jurnal Ekonomi Syariah Teori dan Terapan, 2(9), 698-712.

Andansari, N. A., Raharjo, K., \& Andini, R. (2016). Pengaruh return on equity (ROE), price earning ratio (PER), total asset turn over (TATO) dan price to book value (PBV) terhadap return saham. Jurnal Akuntansi Keuangan dan Bisnis, 2(2), 2-10.

Astarina, Y., Dimyati, L., \& Sari, W. N. (2019). Pengaruh kebijakan dividen terhadap return saham pada perusahaan industri manufaktur yang terdaftar di Bursa Efek Indonesia. Jurnal Ekonomia, 9(2), 72-81.

Astuti, R., Lapian, J., \& Rate, P. V. (2016). Pengaruh faktor makro ekonomi terhadap indeks harga saham gabungan (IHSG) di Bursa Efek Indonesia (BEI) Periode 2006-2015. Jurnal Berkala Ilmiah Efisiensi, 16(2), 399-406.

Atmaja, L. S. (2009). Dividend policy in Australia. Jurnal Keuangan dan Perbankan, 13(2), 260270.

Ayem, S., \& Nugroho, R. (2016). Pengaruh profitabilitas, struktur modal, kebijakan dividen, dan keputusan investasi terhadap nilai perusahaan. Jurnal Akuntansi, 4(1), 31-39.

Cahyono, J. E. (2000). Menjadi manajer investasi bagi diri sendiri. Jakarta: Gramedia Pustaka Utama.

Connelly, B. L., Certo, S. T., Ireland, R. D., \& Reutzel, C. R. (2011). Signaling theory: a review and assessment. Journal of Management, 37(1), 39-67.

Efni, Y. (2009). Pengaruh suku bunga deposito, sbi, kurs dan inflasi terhadap harga saham perusahaan real estate dan property di BEI. Working Paper.

Firmansyah, A., Sihombing, P., \& Kusumastuti, S. R. (2020). The determinants of idiosyncratic volatility in Indonesia banking industries. Jurnal Keuangan dan Perbankan, 24(2), 175-188

Fitri, R. (2017). Pengaruh kebijakan dividen, leverage perusahaan dan profitabilitas terhadap return saham. Jurnal Ilmiah Bisnis dan Ekonomi Asia, 11(2), 32-37. 
Geno, M. R. P., Nuradmanta, R. W., Firmansyah, A. (2020). Return saham perusahaan subsektor properti dan real estate di Indonesia: rasio likuiditas, rasio solvabilitas, degree of leverage. Moneter: Jurnal Keuangan dan Perbankan, 8(2), 65-78.

Gumanti, T. A. (2009). Teori sinyal dalam manajemen keuangan. jurnal manajemen dan usahawan Indonesia. Working Paper.

Kusumawati, D. A. P. (2016). Pengaruh keputusan investasi, keputusan pendanaan, dan kebijakan dividen terhadap return saham pada perusahaan manufaktur Di Bursa Efek Indonesia periode 2010-2014. Working Paper.

Mahilo, B., \& Parengkuan, T. (2015). Dampak risiko suku bunga, inflasi, dan kursterhadap returnsaham perusahaan makanan dan minuman yang go public di Bursa Efek Indonesia. Jurnal EMBA, 3(3), 1-10.

Mladenoska, A. (2017). The Impact of Dividend Policy on Share Price Volatility in the Macedonian Stock Market. Journal of Contemporary Economic and Business Issues, 4(2), 37-50.

Mondayri, S., Basyir, M. F., \& Firmansyah, A. (2020). Return saham dari sudut pandang kinerja operasi perusahaan dan ukuran perusahaan. Jurnal Online Insan Akuntan, 5 (2), 271-283

Murwaningsari, E. (2012). Pengaruh struktur kepemilikan terhadap return saham. Media Riset Akuntansi, Auditing \& Informasi, 12(1), 45-60.

Nasir, A., \& Mirza, A. (2011). Pengaruh nilai kurs, inflasi, suku bunga deposito dan volume perdagangan saham terhadap return saham pada perusahaan perbankan yang terdaftar di Bursa Efek Indonesia. Jurnal Ekonomi Universitas Riau, 19(4).

Nuraeni, N. (2012). Pengaruh EPS, ROE, dan struktur kepemilikan institusional saham terhadap harga saham (studi pada perusahaan rokok yang listing di BEI tahun 20052011. Agromix, 3(2), 36-54.

Piristina, F. A., \& Khairunnisa. (2019). Analisis pengaruh kebijakan dividen, keputusan investasi, dan keputusan pendanaan terhadap nilai perusahaan. Jurnal Aset (Akuntansi Riset), 11(1), 123-136.

Pratiwi, P. (2015). Pengaruh kebijakan dividen terhadap return saham pada perusahaan sektor industri barang konsumsi yang terdaftar di Bursa Efek Indonesia. Jurnal Financial, $1(1), 50-55$.

Purnamasari, L. (2017). Pengaruh return on asset dan return on equity terhadap return saham. Working Paper.

Putra, I. M. G. D., \& Dana, I. M. (2016). Pengaruh profitabilitas, leverage, likuiditas, dan ukuran perusahaan terhadap return saham perusahaan farmasi di BEI. E-Jurnal Manajemen Unud, 5(11), 6825-6850.

Raningsih, N., \& Putra, I. M. G. D. (2015). Pengaruh rasio-rasio keuangan dan ukuran perusahaan pada return saham. E-Jurnal Akuntansi, 13(2), 582-598.

Setyaningrum, R. \& Muljono, M. (2016). Pengaruh inflasi, tingkat suku bunga dan nilai tukar terhadap return saham. E-Jurnal Manajemen, 14(2), 152-160.

Suriyani, N., Sudiartha, \& Mertha, G. (2018). Pengaruh tingkat sukubunga, inflasi dan nilai tukar terhadap return saham di Bursa EfekIndonesia. E-Jurnal Manajemen, 7(6), 31723200. 
Jurnal Terapan Manajemen dan Bisnis

Volume 7 Number 1 March 2021. Page 12-23

e-ISSN: 2477-5282 p-ISSN: 2599-3127

Tumonggor, M., Murni, S., \& Van Rate, P. (2017). Analisis pengaruh current ratio, return on equity, debt to equity ratio dan growth terhadap return saham pada cosmetics and household industry yang terdaftar di BEI Periode 2010-2016. Jurnal EMBA, 5(2), 2203-2210.

https://finance.detik.com/bursa-dan-valas/d-4972595/perjalanan-ihsg-sejak-ripositif-viruscorona 